\title{
Linking feeding ecology and population abundance: a review of food resource limitation on primates
}

Received: 2 July 2012/ Accepted: 22 November 2012 / Published online: 12 December 2012

(C) The Ecological Society of Japan 2012

\begin{abstract}
We review studies that consider how food affects primate population abundance. In order to explain spatial variation in primate abundance, various correlates that parameterize quality and quantity of food in the habitat have been examined. We propose two hypotheses concerning how resource availability and its seasonality determine animal abundance. When the quality of fallback foods (foods eaten during the scarcity of preferred foods) is too low to satisfy nutritional requirement, total annual food quantity should determine population size, but this relationship can be modified by the quality or the quantity of fallback foods. This mechanism has been established for Japanese macaques and sportive lemurs that survive lean seasons by fat storage or extremely low metabolism. Second, when fallback food quality is high enough to satisfy nutritional requirement but quantity is limited, quantity of fallback food should be a limiting factor of animal abundance. This is supported by the correlation between fig density, which is a high-quality fallback food, and gibbon and orangutan abundance. For a direct test of these hypotheses, we need more research that determines both the quality of food that animals require to satisfy their nutritional requirement and the quantity of food production. Leaves are often regarded as superabundant, but this assumption needs careful examination.
\end{abstract}

Keywords Bottleneck P Population density $\cdot$ Fallback food $\cdot$ Nutrition $\cdot$ Seasonality

Goro Hanya is the recipient of the 5th Yasuyuki Oshima Award.

\section{G. Hanya $(\bowtie)$}

Primate Research Institute, Kyoto University, Inuyama,

Aichi 484-8506, Japan

E-mail: hanya@pri.kyoto-u.ac.jp

Tel.: + 81-568-630542

Fax: + 81-568-630564

C. A. Chapman

Department of Anthropology and McGill School of Environment, McGill University, Montreal, Canada

\section{Introduction}

One of the primary goals in animal ecology is to reveal how environmental factors determine animal abundance. This topic has recently taken on a heightened significant as many animal populations are declining under increasing human pressure, and understanding the factors affecting their populations is necessary for conservation and management. Although various factors, such as climate (Iwamoto and Dunbar 1983; Barton and Zalewski 2007), predation (Peek 1980; Isbell 1990), and stress or disease (Milton 1996; Harvell et al. 1999; Berger et al. 2001; Chapman et al. 2006), can affect animal abundance, the effect of food has typically been considered of paramount importance.

Primates are ideal subjects to study both animal abundance and feeding ecology. Since they are diurnal and standardized census methods are established (National Research Council 1981; Whitesides et al. 1988), comparable data on abundance are available for many species, often from a number of populations. Furthermore, since most primates are diurnal and have large body sizes, detailed behavioral observation is feasible and there have been many studies of their feeding ecology (Clutton-Brock 1977; Hohmann et al. 2006). Primates are generalist consumers and are dependent on a diverse array of resources, such as leaves, fruits/seeds, flowers, gum/sap, barks, and insects (Kay 1984). These food resources vary in their nutritional and distributional properties, thus comparative primate research can clarify various mechanisms concerning how food affects abundance.

For primary consumers, the simplest mechanism of food resource (hereafter resource) limitation suggests that habitats can sustain an increasing number of animals up to the point where the total consumption by the population equals the production of food by the plant community. Coelho et al. (1976) concluded that primates are unlikely to be limited by resource, based on 2 months of behavioral observations of two species of 
primates (Alouatta pigra and Ateles geoffroyi). They estimated the primates' energy requirements based on their activity budget, and calculated the total energy requirement of the populations of the two species to be $13,640 \mathrm{kcal} \mathrm{km}^{-2} \mathrm{day}^{-1}$. This was lower than the pulp production of only one species of their main food (Brosimum alicastrum; 716,000 kcal km ${ }^{-2}$ day $^{-1}$ ). These calculations were used to suggest that this one fruiting tree species could sustain 1,700 individuals $\mathrm{km}^{-2}$ of primates, which is implausibly high. This conclusion was criticized by Cant (1980) who pointed out that (1) food availability changes both seasonally and supra-annually and one cannot conclude that animals are free from resource limitation with only 2 months of data; and (2) food quality was not considered. He argued that even if resources are super-abundant in most seasons, animals experience "ecological crunches" when resources are in short supply and their populations can be limited by these periods. In the three decades since the publication of these papers a great deal of data on primate feeding ecology and population abundance has accumulated that can be matched to data on forest productivity and food quality, thus now is the time to revisit Cant's (1980) question: "What limits primates?"

In this paper, we review studies on primate abundance at the population level and propose hypotheses concerning the mechanism of resource limitation under seasonally fluctuating conditions. Subsequently, we critically evaluate what information is necessary to test these hypotheses and discuss future research directions.

\section{Approaches to study resource limitation at the population level}

Approaches to study resource limitation at the population level can be categorized as dynamic or static. Animal populations often fluctuate in size over time and the dynamic approach examines the environmental factors that correlate with changes in population size between one period and the next. One can also manipulate environmental factors experimentally and observe the numerical response to it over time. The static approach compares the natural variation in animal abundance among different ecological settings over space and examines which environmental factors correspond to the differences. Although the dynamic approach can tell the immediate cause of population changes (i.e., one can identify what environmental factor changed just prior to the population change), it does not necessarily reveal why the abundance in one population is higher than the others, or which difference far exceeds the degree of variability of one population.

Primates have been studied largely using the static approach. If animals change their number rapidly, as seen with rodent population cycles or ungulate migrations (Kaji et al. 1988; Wolff 1996), the static approach may not be useful. Although many primates change their number over time, the scale over a year or the duration of most studies is much smaller than that of many other mammals (Hanya 2009). Experiment on resource limitation in primates is usually difficult because both spatial and time scales are too large for researchers to mimic. For example, provisioning or food removal experiments with rodents and pigeons were conducted at a scale of 1.7-3.5 ha and 1.8 ha, respectively (Adler 1998; Moegenburg and Levey 2003), which is much smaller than a home range of a single group of most diurnal primates (5 ha-24 km²) (Mitani and Rodman 1979). Large-scale provisioning of free-ranging primates is conducted mainly for tourism or for management of introduced colonies. Although their effect on population changes has been confirmed (Mori 1979a; Sugiyama and Ohsawa 1982; Watanabe et al. 1992), food abundance has been manipulated for management, not for research on resource limitation. These studies took several decades to observe population changes, which is much longer than the response observed in rodent or pigeon studies ( $<1$ year) (Adler 1998; Moegenburg and Levey 2003). Therefore, although data on provisioned populations directly tests whether primates are food limited, studies based on the comparison of natural populations are indispensable in exploring natural mechanism of resource limitation.

\section{Previous studies on primate abundance}

Density has been estimated for many primate populations, but only a small proportion of these studies have examined the environmental factors affecting variation among populations (static) or within a population over time (dynamic). Of those that do speculate on environmental drivers of density, the majority only make qualitative comparisons among vegetation types or study sites (Freese et al. 1982; Weisenseel et al. 1993; White 1994; Yoshihiro et al. 1999; Mathews and Matthews 2002; McConkey and Chivers 2004). Other studies examined vegetational correlates of primate abundance, such as tree density, basal area, shrub cover, and tree species diversity (Butynski 1990; Chapman and Chapman 1999; Balcomb et al. 2000; Wieczkowski 2004; Worman and Chapman 2006; Hamard et al. 2010). While this is useful information regarding habitat preference, their ability to determine determinants of animal abundance is limited. For example, vegetation structure evaluates food quantity only in the most general way. Such studies do not evaluate the seasonal changes in food availability, the importance of fallback foods (foods that are eaten during the scarcity of preferred foods), or the type of resource limiting the animal.

Such studies examining vegetational correlates of primate abundance can be used in meta-analyses; however, since it is usually difficult to collect data on both primate and habitat variables in a comparable fashion, primate abundance is usually correlated with indirect 
measure of forest productivity, such as rainfall or forest type. Forest type can explain the difference in primate abundance in a rudimentary fashion (Ganzhorn et al. 1999; Peres 1999; Peres and Dolman 2000), but climate usually cannot (Chapman and Balcomb 1998; Gupta and Chivers 1999; van Schaik et al. 2005). However, using direct measures of food abundance, such as fruit fall, significant results are found (Stevenson 2001).

Studies on folivorous primates are exceptional because a single habitat parameter is known to correlate with their biomass. Milton (1979) proposed that the protein-to-fiber ratio of leaves was an important criterion for leaf selection by primates, whereby leaves with higher protein and low fiber ratios were selected. This preference has been demonstrated for a large number of primates (Chapman and Chapman 2002; Ganzhorn 2002; Hanya and Bernard 2012). Fiber is often considered an antifeedant because it requires fermentation by symbiotic microbes and the cellulose and hemicellulose components of the fiber is typically only partially digestible by folivores (McNab 2002). Furthermore, nitrogen is the limiting nutrient in many terrestrial ecosystems and since it is found primarily in protein, herbivores should compensate for this limitation by choosing high protein foods (White 1993). These important ideas proposed by Milton have been applied at the population level by others (McKey et al. 1981; Waterman et al. 1988; Oates et al. 1990; Davies 1994; Chapman et al. 2002). For example, Waterman et al. (1988) proposed that the weighted contributions of the protein-to-fiber ratios of the mature leaves of the most abundant trees in a particular area could predict the biomass of folivorous colobines. This index of dietary quality has been applied successfully to predict the biomass of folivorous monkeys at local (Chapman et al. 2002; Ganzhorn 2002) and regional (Waterman et al. 1988; Oates et al. 1990; Ganzhorn 1995; Chapman et al. 2004; Fashing et al. 2007) scales. Davies (1994) suggested that the year-round availability of digestible mature leaves with high protein-to-fiber ratios, which are used by colobus species when other, more preferred foods are unavailable, serves to limit the size of colobine populations (i.e., high protein-to-fiber mature leaves are important fallback foods). However, some colobines rarely eat mature leaves since young leaves are always available, yet their biomass can still be predicted by this index (Chapman et al. 2004). Thus, the protein-to fiber ratio of mature leaves in an area may be correlated with the protein-to-fiber ratio of foods in general. This is supported by the fact that, in a sample of leaves from Kibale National Park, Uganda, it was documented that the protein-to-fiber ratio of mature and young leaves were strongly correlated $(r=0.837$, $P<0.001$; Chapman et al. 2004). Thus, measuring the protein-to-fiber ratio of mature leaves may be useful because it correlates with the general availability of highprotein, low-fiber foods, and thus is a useful index of habitat quality for colobus monkeys. The mechanism on how this parameter affects primate abundance remains unclear as this ratio may correlate with other leaf constituents that really drive the relationship (Chapman et al. 2002). For example, Wallis et al. (2012) suggests that the available nitrogen concentration of leaves, which covers both fiber and tannin content, is a real influencing factor on folivore leaf choice. More research is needed to determine why the protein-to-fiber index predicts folivore biomass.

Studies of frugivorous primates similarly indicate the importance of food resources, but suggest that, in addition to food quantity, seasonality is also critical in regulating primate populations. For example, Hanya et al. (2004) examined the effects of both total annual fruit production and the degree of seasonality in fruiting (number of months when no fruit is available) on the density of a Japanese macaque (Macaca fuscata) population in Yakushima. They indicated that total annual fruit production affected density more than seasonality. Japanese macaques survive the lean season (winter) not only by consuming the food available during that period (mature leaves) but also by using the fat accumulated by eating fruits and seeds during the period of high fruit availability (Hanya 2004). Therefore, in an altitudinal zone where fruit production is low, macaques need to range over a large area to accumulate sufficient fat stores and, as a result, density is low. Hanya et al. (2006) tested this idea through a meta-analysis across the species range and documented that density was consistently higher in evergreen as compared to deciduous habitats (Takasaki 1981a, b; Hanya et al. 2006). In winter, Japanese macaques rely on mature leaves in evergreen forest and on buds and barks in deciduous forest (Iwamoto 1982; Nakagawa 1989a; Hill 1997; Tsuji et al. 2008); thus, food deficiency in winter is more severe in deciduous than in evergreen forests (Nakagawa et al. 1996). Therefore, even if the total annual fruit production is constant, macaques in deciduous forest need to range over a larger area before winter to accumulate sufficient fat stores to survive the winter. In fact, home range size tends to be the largest in summer or autumn, not in winter (Hanya et al. 2006). The combined influence of the seasonality and total annual food abundance on primates is supported by the meta-analysis of 16 frugivorous primate communities in the Old and New Worlds (Hanya et al. 2011). In this study, the best-fit model predicting primate abundance included both total annual fruit fall $(+)$ and its seasonality $(-$, assessed by coefficient of variation of monthly fruit fall). This result suggests that, when food availability varies seasonally, primates have access to less food or lower-quality food during the food-scarce season than when food is equally available throughout the year.

\section{Coping with seasonality: two hypotheses on resource limitation}

Primates respond primarily to seasonal variation of food availability by shifting their diet (van Schaik et al. 1993). 
Recent studies on primate feeding ecology have categorized foods into preferred and fallback foods (Lambert 2007; Marshall and Wrangham 2007; Marshall et al. 2009). Preferred food is one that is of high quality and is eaten more than the relative abundance in the habitat. Availability of preferred foods is usually limited and its seasonal consumption correlates with that of availability. Fallback food is one which is of lower quality than preferred foods but available throughout the year and eaten when preferred foods are less available. Among the above-mentioned Japanese macaque foods, for example, fruit and seed are preferred foods, and mature leaf, bud, and bark are fallback foods (Hanya 2004; Tsuji et al. 2008). Fallback foods can vary in quality from those that are sufficiently nutritious to support the population to those that cannot (Lambert 2007).

Which is more important in limiting primate populations, preferred or fallback foods? This question is central to the problem of how seasonality affects primate abundance. Food may be sufficiently abundant most of the year, but when it decreases dramatically in one season, it may act as an "ecological crunch" or "bottleneck" and primate density may be limited by food availability only during this lean season (Cant 1980). From this view, fallback foods could serve as limiting factors of primate abundance. Studies on Japanese macaques indicate that both fallback food quality and total annual abundance of preferred food affect macaque density (Hanya et al. 2004, 2006). However, three conditions influence the nature of how fallback food influence populations: (1) animals cannot satisfy nutritional requirements only by fallback foods; (2) animals are capable of "saving" foods, such as fat accumulation or scatter-hoarding; and (3) fallback food is superabundant. With regard to the first condition, some primates rely on fallback foods that are of higher quality, such as fig fruits, than those of Japanese macaques (Lambert 2007). Unlike Japanese macaques, animals may be able to satisfy nutritional requirements with these foods, but availability is expected to be limited (Lambert 2007). In fact, fig tree density correlates with orangutan (Pongo abelii) and gibbon (Hylobates spp.) density in some locations (Wich et al. 2004; Marshall and Leighton 2006). Gibbon density was not correlated with the overall food tree density, suggesting abundance of fallback food is more important than the total annual food availability (Marshall and Leighton 2006). Concerning the second condition, fat accumulation has been reported in temperate macaques, orangutans, many lemurs, and humans (Wada 1975; Zhao 1994; Knott 1998; Atsalis 1999; Muroyama et al. 2006), but it has not been examined carefully for most species. As for the third condition, leaves are often considered a superabundant fallback food; however, the quality of leaves is quite variable and primates are very selective with respect to leaf quality (Milton 1979; Ganzhorn 1992; Chapman and Chapman 2002; Hanya and Bernard 2012). To determine if leaves can be a superabundant fallback food, we need to know if the leaf quality that is required for the animal's digestive ability to extract sufficient nutrients is suitable, and that leaf production of this required quality is sufficiently high to maintain the primate population. This information is generally unavailable, but there is a growing body of evidence that even folivorous primates experience food competition (Snaith and Chapman 2007; Tombak et al. 2012).

Based on this, we propose two hypotheses concerning mechanisms of resource limitation (Table 1). First, when fallback food quality is too low to satisfy nutritional requirement but it is superabundant, total annual food quantity of preferred foods should affect animal abundance. This relationship can be modified by the quality (condition $\mathrm{C}$ in Table 1) of fallback foods. Fat-accumulating Japanese macaques are one example (Hanya et al. 2004) for the hypothesis, but an example of folivorous sportive lemur (Lepilemur ruficaudatus) may suggest that another mechanism is feasible for this hypothesis to work. This species eat nutrient-rich young

Table 1 Hypotheses on the mechanism of food resource limitation on primates with respect to the quality and abundance of fallback foods

\begin{tabular}{|c|c|c|c|c|}
\hline Condition & $\begin{array}{l}\text { Quality of fallback } \\
\text { food is enough to } \\
\text { satisfy nutrition } \\
\text { requirement }\end{array}$ & $\begin{array}{l}\text { Abundance of } \\
\text { fallback food }\end{array}$ & $\begin{array}{l}\text { Mechanism of resource } \\
\text { limitation }\end{array}$ & Possible examples \\
\hline A & Yes & Superabundant & $\begin{array}{l}\text { (Not limited by } \\
\text { food resource) }\end{array}$ & $\begin{array}{l}\text { Mentawai leaf monkeys } \\
\text { (Watanabe 1981) living } \\
\text { at extremely high density }\end{array}$ \\
\hline B & Yes & Limited & $\begin{array}{l}\text { Limited by the quantity } \\
\text { of fallback food }\end{array}$ & $\begin{array}{l}\text { Gibbons and orangutans } \\
\text { depending on fig fruits } \\
\text { as fallback foods } \\
\text { (Wich et al. 2004; } \\
\text { Marshall and Leighton 2006) }\end{array}$ \\
\hline $\mathrm{C}$ & No & Superabundant & $\begin{array}{l}\text { Limited by the quantity } \\
\text { of preferred food }\end{array}$ & $\begin{array}{l}\text { Japanese macaques } \\
\text { (Hanya et al. 2004), } \\
\text { sportive lemurs } \\
\text { (Ganzhorn 2002) }\end{array}$ \\
\hline $\mathrm{D}$ & No & Limited & $\begin{array}{l}\text { Limited by the quantity } \\
\text { of either preferred or } \\
\text { fallback food }\end{array}$ & - \\
\hline
\end{tabular}


leaves and reproduce in the wet season and fall back to mature leaves in the dry season when young leaves are not available. They survive the lean season by keeping an extremely low metabolic rate and low levels of activity (Schmid and Ganzhorn 1996). Their abundance correlates with the product of quantity (number of food trees) and quality (protein to fiber ratio) of young leaves during the food-abundant wet season (Ganzhorn 2002). This index would likely correlate with the quantity of young leaves that is above a certain level of nutritional quality, thus the findings of this species support our hypothesis.

Second, when fallback food quality is high enough to satisfy nutritional requirements, but their quantity is limited, quantity of fallback food should determine animal abundance (condition B in Table 1). Gibbons and orangutans, which are limited by fig density, support this hypothesis (Wich et al. 2004; Marshall and Leighton 2006). Whether food saving adaptations modifies the relationships depends on the animal's saving ability, their activity and metabolic levels, and on the required home range size to secure fallback and preferred foods.

In addition to the above two conditions, two more conditions are conceivable. When fallback food quality is too low to satisfy nutritional requirement, and its quantity is limited (condition D), we cannot make predictions because in principle both preferred and fallback food quantity can affect animal abundance. We expect that animal abundance would be determined by the food that is more limited (i.e., the one that requires larger home range to secure the species requirements). When fallback food quality is high enough to satisfy nutritional requirement and quantity is superabundant, animals are, in principle, not limited by food (conditions A). It is not clear whether this last condition occurs naturally, but colobines living at extremely high density, exceeding 200 individuals $\mathrm{km}^{-2}$ (Watanabe 1981), may be included in this category. In fact, Yeager and Kirkpatrick (1998) consider the abundance of Asian colobines to be limited by non-food factors, such as social stress. However, the assumed quantity and quality of fallback foods available to colobines has recently been questioned (Snaith and Chapman 2007).

\section{Studies on resource limitation at the behavioral level}

It is important to know whether animals can satisfy their nutritional requirements by the consumption of fallback foods. The simplest means of examining this is to quantify if the animals' intake is lower than their requirements. For Japanese macaques, their energy intake becomes only $60-90 \%$ of the requirement in winter, when they fall back to mature leaves, buds, and barks (Iwamoto 1982; Nakagawa 1989a; Tsuji et al. 2008). They become energy deficiency in two ways (Nakagawa et al. 1996). First, the energy content of mature leaves that are their fallback foods is sometimes so low that animals cannot extract sufficient nutrients even if they eat up to their gut capacity (Mori 1979b). Second, some foods, such as buds, are so small that animals cannot eat enough even if they spend most of their day feeding (Nakagawa et al. 1996). In fact, Japanese macaques in deciduous forest spend almost $70 \%$ of their day feeding in the winter (Nakagawa 1989b).

Deficiency in macronutrients can also be shown by urinalysis that quantify ketone and c-peptide concentrations as indices of energy balance (Harris et al. 2009; Harrison et al. 2010; MacIntosh et al. 2012) and urea and $\delta^{15} \mathrm{~N}$ for protein balance (Vogel et al. 2012a). Using these techniques, Bornean orangutans (Pongo pygmaeus) are shown to suffer from severe energy and protein deficiencies during periods of fruit scarcity (Knott 1998; Vogel et al. 2012b).

Animals showing no sign of negative energy or protein balance may still suffer from resource limitation. Animals may prioritize the intake of one nutrient over others, which can lead to consuming some nutrients more than needed. Geometrical framework of nutrition intake is a model allowing one to examine difference in priority among nutrients. To date we are aware of only two examples of application of this method in primate feeding ecology, and the results show interesting differences among species. Frugivorous spider monkeys (Ateles chamek) prioritize protein intake over energy (i.e., although the carbohydrate and lipid intake varies between 0.7 and $20 \mathrm{MJ} \mathrm{day}^{-1}$, their protein intake remained constant $(0.19 \mathrm{MJ} \pm 0.01 \mathrm{SE}$ ) (Felton et al. 2009). In contrast, mountain gorillas (Gorilla gorilla) prioritize non-protein energy over protein intake (Rothman et al. 2011). Spider monkeys lack adaptations to extract protein from leaves, thus they need to ingest a great deal of fruit to keep a constant protein intake. While, because of their large size and digestive system, gorillas can gain sufficient protein from leaves and herbaceous material, so they must secure carbohydrates and lipids in the fruit-poor environment.

In addition to macronutrients, animals may also be limited by micronutrients, such as minerals or vitamins (Janson and Chapman 1999). Currently very little is known about micronutrient limitation in primates, but several lines of evidence indicates its importance. First, sodium $(\mathrm{Na})$ makes up $90 \%$ of total blood cations and is necessary for animal muscle contraction, nerve impulse transmission, acid-base balance, and metabolism (Robbins 1993), but plants do not require it. Thus, animals eating only plants typically need a sodium source other than their main food. Second, some primates select food with high mineral content (Magliocca and Gautier-Hion 2002; Rode et al. 2003). Third, some primates obtain sodium from unusual feeding locations, such as swamp plants, salt licks, or eucalyptus plantations, and the availability of these locations is often limited (Oates 1978; Harris and Chapman 2007; Matsubayashi et al. 2011). Fourth, mineral availability is known to affect spatial distribution of herbivorous African ungulates (McNaughton 1988) and a colobine monkey (Colobus guereza) (Harris and 
Chapman 2007). To our knowledge, there is only one study that examines the effect of minerals on primate abundance (Rode et al. 2006). Among the four sites within the Kibale National Park, the density of redtail monkeys (Cercopithecus ascanius) was associated with the copper intake level $\left(\mathrm{mg} \mathrm{day}^{-1}\right)$; however, copper availability was not quantified, thus it is difficult to judge what limits this population.

\section{Linking feeding ecology and primate abundance: future perspectives}

To determine if populations are resource limited, we need to identify the limiting nutrients, evaluate the balance between the requirement and actual intake of the nutrients by the animal, and assess the production (in case of macronutrients) or availability (in case of minerals) of that nutrients in the ecosystem. With these data, one can calculate the area that an animal requires to secure enough resources, which in turn determines population density. One must also consider seasonality, and the importance of seasonality can be addressed by examining the hypotheses we proposed here.

Given the time it typically takes for primate populations to respond to a change in the nature of their food resources, there are only a few study sites where the data will be likely to be available to study determinants of primate populations in the way that we have just suggested. However, a convenient alternative means of examining this issue is to analyze seasonal variation in home range size. Population density is the inverse of per capita home range size and is modified by the degree of overlap of home range between neighboring groups (Whitesides et al. 1988). Thus, an index of population density can be obtained during the season when the animal range most extensively, which is likely the season that limits animal abundance. Hanya et al. (2006) suggests that the limiting season for Japanese macaques is summer and autumn because home range size becomes largest at that time. Based on our hypotheses concerning the effect of seasonality on animal abundance, animals that are limited by fallback foods are predicted to have the largest home range in the food-scarce period. In contrast, animals that rely on fat accumulated by eating preferred foods are predicted to range most extensively during the food-rich period.

In conclusion, we propose two mechanisms explaining how resource availability and its seasonality determine animal abundance. When fallback food quality is too low to satisfy nutritional requirements, total annual food quantity affects animal abundance, and this relationship is modified by the quality of fallback foods. When fallback food quality is high enough to satisfy nutritional requirement but quantity is limited, quantity of fallback food is a limiting factor. Examinations of seasonal variations of home range size will be useful to determine the limiting season. For a direct test of the hypotheses, we need to know the threshold value of quality of food that satisfies the animal's nutritional requirements, and the quantity of production in the habitat that supplies nutrients to animals.

Acknowledgments The ideas presented in this review stem mainly from our fieldwork in Yakushima and Kibale. We would like to thank our friends, colleagues and assistants who helped our projects. Thanks also to the Ecological Society of Japan and editors of Ecological Research, for giving us the opportunity to contribute this review. Preparation of this paper was supported financially by the MEXT Grant-in-Aid (No. 22687002) to G.H. and by the Canada Research Chairs Program, and Natural Science and Engineering Research Council of Canada to C.A.C.

\section{References}

Adler GH (1998) Impacts of resource abundance on populations of a tropical forest rodent. Ecology 79:242-254

Atsalis S (1999) Seasonal fluctuations in body fat and activity levels in a rain-forest species of mouse lemur, Microcebus rufus. Int $\mathbf{J}$ Primatol 20:883-910

Balcomb SR, Chapman CA, Wrangham RW (2000) Relationship between chimpanzee (Pan troglodytes) density and large, fleshyfruit tree density: conservation implications. Am J Primatol 51:197-203

Barton KA, Zalewski A (2007) Winter severity limits red fox populations in Eurasia. Glob Ecol Biogeogr 16:281-289

Berger L, Speare R, Thomas A, Hyatt A (2001) Mucocutaneous fungal disease in tadpoles of Bufo marinus in Australia. J Herpetol 35:330-335

Butynski TM (1990) Comparative ecology of blue monkeys (Cercopithecus mitis) in high- and low-density subpopulations. Ecol Monogr 60:1-26

Cant JGH (1980) What limits primates? Primates 21:538-544

Chapman CA, Balcomb SR (1998) Population characteristics of howlers: ecological conditions or group history. Int J Primatol 19:385-403

Chapman CA, Chapman LJ (1999) Implications of small scale variation in ecological conditions for the diet and density of red colobus monkeys. Primates 40:215-231

Chapman CA, Chapman LJ (2002) Foraging challenges of red colobus monkeys: influence of nutrients and secondary compounds. Comp Biochem Physiol A Mol Integr Physiol 133:861-875

Chapman CA, Chapman LJ, Bjorndal KA, Onderdonk DA (2002) Application of protein-to-fiber ratios to predict colobine abundance on different spatial scales. Int J Primatol 23:283-310

Chapman CA, Chapman LJ, Naughton-Treves L, Lawes MJ, McDowell LR (2004) Predicting folivorous primate abundance: validation of a nutritional model. Am J Primatol 62:55-69

Chapman CA, Wasserman MD, Gillespie TR, Speirs ML, Lawes MJ, Saj TL, Ziegler TE (2006) Do food availability, parasitism, and stress have synergistic effects on red colobus populations living in forest fragments? Am J Phys Anthropol 131:525-534

Clutton-Brock TH (1977) Primate ecology: studies of feeding and ranging behaviour in lemurs, monkeys and apes. Academic, Brighton

Coelho AMJ, Bramblett CA, Quick LB, Bramblett SS (1976) Resource availability and population density in primates: a sociobioenergetic analysis of the energy budgets of Guatemalan howler and spider monkeys. Primates 17:63-80

Davies AG (1994) Colobine populations. In: Davies AG, Oates JF (eds) Colobine monkeys: their ecology, behaviour and evolution. Cambridge University Press, Cambridge, pp 285-310

Fashing PJ, Dierenfeld ES, Mowry CB (2007) Influence of plant and soil chemistry on food selection, ranging patterns, and biomass of Colobus guereza in Kakamega Forest, Kenya. Int J Primatol 28:673-703 
Felton AM, Felton A, Raubenheimer D, Simpson SJ, Foley WJ, Wood JT, Wallis IR, Lindenmayer DB (2009) Protein content of diets dictates the daily energy intake of a free-ranging primate. Behav Ecol 20:685-690

Freese CH, Heltne PG, Castro RN, Whitesides G (1982) Patterns and determinants of monkey densities in Peru and Bolivia, with notes on distributions. Int J Primatol 3:53-90

Ganzhorn JU (1992) Leaf chemistry and the biomass of folivorous primates in tropical forests: test of a hypothesis. Oecologia 91:540-547

Ganzhorn JU (1995) Low level forest disturbance effects on primary production, leaf chemistry, and lemur populations. Ecology 76:2084-2096

Ganzhorn JU (2002) Distribution of a folivorous lemur in relation to seasonally varying food resources: integrating quantitative and qualitative aspects of food characteristics. Oecologia $131: 427-435$

Ganzhorn JU, Wright PC, Ratsimbazafy J (1999) Primate communities: Madagascar. In: Fleagle J, Janson C, Reed K (eds) Primate communities. Cambridge University Press, Cambridge, pp 75-89

Gupta A, Chivers D (1999) Biomass and use of resources in south and south-east Asian primate communities. In: Fleagle J, Janson C, Reed K (eds) Primate communities. Cambridge University Press, Cambridge, pp 38-54

Hamard M, Cheyne SM, Nijman V (2010) Vegetation correlates of gibbon density in the peat-swamp forest of the Sabangau Catchment, Central Kalimantan, Indonesia. Am J Primatol $72: 607-616$

Hanya G (2004) Diet of a Japanese macaque troop in the coniferous forest of Yakushima. Int J Primatol 25:55-71

Hanya G (2009) Primate population dynamics: long-term data on the fluctuations of population size (in Japanese with English summary). Primate Res 24:221-228

Hanya G, Bernard H (2012) Fallback foods of red leaf monkeys (Presbytis rubicunda) in Danum Valley, Borneo. Int J Primatol 33:322-337

Hanya G, Yoshihiro S, Zamma K, Matsubara H, Ohtake M, Kubo R, Noma N, Agetsuma N, Takahata Y (2004) Environmental determinants of the altitudinal variations in relative group densities of Japanese macaques on Yakushima. Ecol Res 19:485-493

Hanya G, Kiyono M, Yamada A, Suzuki K, Furukawa M, Yoshida Y, Chijiiwa A (2006) Not only annual food abundance but also fallback food quality determines the Japanese macaque density: evidence from seasonal variations in home range size. Primates 47:275-278

Hanya G, Stevenson P, van Noordwijk M, Wong ST, Kanamori T, Kuze N, Aiba S, Chapman CA, van Schaik C (2011) Seasonality in fruit availability affects frugivorous primate biomass and species richness. Ecography 34:1009-1017

Harris TR, Chapman CA (2007) Variation in diet and ranging of black and white colobus monkeys in Kibale National Park, Uganda. Primates 48:208-221

Harris TR, Chapman CA, Monfort SL (2009) Small folivorous primate groups exhibit behavioral and physiological effects of food scarcity. Behav Ecol 21:46-56

Harrison ME, Morrogh-Bernard HC, Chivers DJ (2010) Orangutan energetics and the influence of fruit availability in the nonmasting peat-swamp forest of Sabangau, Indonesian Borneo. Int J Primatol 31:585-607

Harvell CD, Kim K, Burkholder JM, Colwell RR, Epstein PR, Grimes DJ, Hofmann EE, Lipp EK, Osterhaus A, Overstreet RM, Porter JW, Smith GW, Vasta GR (1999) Review: Marine ecologyâ€"emerging marine diseasesâ€"climate links and anthropogenic factors. Science 285:1505-1510

Hill DA (1997) Seasonal variation in the feeding behavior and diet of Japanese macaques (Macaca fuscata yakui) in lowland forest of Yakushima. Am J Primatol 43:305-322

Hohmann G, Robbins MM, Boesch C (2006) Feeding ecology in apes and other primates: ecological, physiological and behavioral aspects. Cambridge University Press, Cambridge
Isbell LA (1990) Sudden short-term increase in mortality of vervet monkeys (Cercopithecus aethiops) due to leopard predation in Amboseli National Park, Kenya. Am J Primatol 21:41-52

Iwamoto T (1982) Food and nutritional condition of free ranging Japanese monkeys on Koshima Islet during winter. Primates 23:153-170

Iwamoto T, Dunbar RIM (1983) Thermoregulation, habitat quality and the behavioral ecology of gelada baboons. J Anim Ecol 52:357-366

Janson C, Chapman C (1999) Resources and primate community structure. In: Fleagle J, Janson C, Reed K (eds) Primate communities. Cambridge University Press, Cambridge, pp 237-267

Kaji K, Koizumi T, Ohtaishi N (1988) Effects of resource limitation on the physical and reproductive condition of sika deer on Nakanoshima Island, Hokkaido. Acta Theriol 33:187-208

Kay RF (1984) On the use of anatomical features to infer foraging behavior in extinct primates. In: Rodman PS, Cant JGH (eds) Adaptations for foraging in nonhuman primates: contributions to an organismal biology of prosimians, monkeys, and apes. Columbia University Press, New York, pp 21-53

Knott CD (1998) Changes in orangutan caloric intake, energy balance, and ketones in response to fluctuating fruit availability. Int J Primatol 19:1061-1079

Lambert JE (2007) Seasonality, fallback strategies, and natural selection: a chimpanzee and Cercopithecoid model for interpreting the evolution of the hominin diet. In: Ungar PS (ed) Evolution of the human diet: the known, the unknown, and the unknowable. Oxford University Press, Oxford, pp 324-343

MacIntosh AJJ, Huffman MA, Nishiwaki K, Miyabe-Nishiwaki T (2012) Urological screening of a wild group of Japanese macaques (Macaca fuscata yakui): investigating trends in nutrition and health. Int J Primatol 33:460-478

Magliocca F, Gautier-Hion A (2002) Mineral content as a basis for food selection by western lowland gorillas in a forest clearing. Am J Primatol 57:67-77

Marshall A, Leighton M (2006) How does food availability limit the population density of white-bearded gibbons? In: Hohmann G, Robbins M, Boesch C (eds) Feeding ecology in apes and other primates: ecological, physical and behavioral aspects. Cambridge University Press, New York, pp 313-335

Marshall AJ, Wrangham RW (2007) Evolutionary consequences of fallback foods. Int J Primatol 28:1218-1235

Marshall AJ, Boyko CM, Feilen KL, Boyko RH, Leighton M (2009) Defining fallback foods and assessing their importance in primate ecology and evolution. Am J Phys Anthropol 140:603-614

Mathews A, Matthews A (2002) Distribution, population density, and status of sympatric cercopithecids in the Campo-Máan area, Southwestern Cameroon. Primates 43:155-168

Matsubayashi H, Ahmad AH, Wakamatsu N, Nakazono E, Takyu M, Majalap N, Lagan P, Sukor JRA (2011) Natural-licks use by orangutans and conservation of their habitats in Bornean tropical production forest. Raffles Bull Zool 59:109-115

McConkey KR, Chivers DJ (2004) Low mammal and hornbill abundance in the forests of Barito Ulu, Central Kalimantan, Indonesia. Oryx 38:439-447

McKey DB, Gartlan JS, Waterman PG, Choo GM (1981) Food selection by black colobus monkeys (Colobus satanas) in relation to plant chemistry. Biol J Linn Soc 16:115-146

McNab BK (2002) The physiological ecology of vertebrates: a view from energetics. Cornell University Press, Cornell

McNaughton SJ (1988) Mineral nutrition and spatial concentrations of African ungulates. Nature 334:343-345

Milton K (1979) Factors influencing leaf choice by howler monkeys: test of some hypotheses of food selection by generalist herbivores. Am Nat 114:362-378

Milton K (1996) Effects of bot fly (Alouattamyia baeri) parasitism on a free-ranging howler monkey (Alouatta palliata) population in Panama. J Zool 239:39-63

Mitani JC, Rodman PS (1979) Territoriality: relation of ranging pattern and home range size to defendability, with an analysis of territoriality among primate species. Behav Ecol Sociobiol $5: 241-251$ 
Moegenburg SM, Levey DJ (2003) Do frugivores respond to fruit harvest? An experimental study of short-term responses. Ecology 84:2600-2612

Mori A (1979a) Analysis of population changes by measurement of body weight in the Koshima troop of Japanese monkeys. Primates 20:371-397

Mori A (1979b) An experiment on the relation between the feeding speed and the caloric intake through leaf eating in Japanese monkeys. Primates 20:185-195

Muroyama Y, Kanamori H, Kitahara E (2006) Seasonal variation and sex differences in the nutritional status in two local populations of wild Japanese macaques. Primates 47:355-364

Nakagawa N (1989a) Bioenergetics of Japanese Monkeys (Macaca fuscata) on Kinkazan Island during winter. Primates $30: 441-460$

Nakagawa N (1989b) Feeding strategies of Japanese monkeys against deterioration of habitat quality. Primates 30:1-16

Nakagawa N, Iwamoto T, Yokota N, Soumah AG (1996) Interregional and inter-seasonal variations of food quality in Japanese macaques: constraints of digestive volume and feeding time. In: Fa JE, Lindburg DG (eds) Evolution and ecology of macaque societies. Cambridge University Press, New York, pp 207-234

National Research Council (1981) Techniques for the study of primate population ecology. National Academy Press, Washington, DC

Oates JF (1978) Water-plant and soil consumption by guereza monkeys (Colobus guereza): relationship with minerals and toxins in the diet. Biotropica 10:241-253

Oates JF, Whitesides GH, Davies AG, Waterman PG, Green SM, Dasilva GL, Mole S (1990) Determinants of variation in tropical forest primate biomass: new evidence from West Africa. Ecology 71:328-343

Peek JM (1980) Natural regulation of ungulates (what constitutes a real wilderness?). Wildl Soc Bull 8:217-227

Peres C (1999) Effects of subsistence hunting and forest types on the structure of Amazonian primate communities. In: Fleagle J, Janson C, Reed K (eds) Primate communities. Cambridge University Press, Cambridge, pp 268-283

Peres CA, Dolman PM (2000) Density compensation in neotropical primate communities: evidence from 56 hunted and nonhunted Amazonian forests of varying productivity. Oecologia 122:175-189

Robbins CT (1993) Wildlife feeding and nutrition. Academic, New York

Rode KD, Chapman CA, Chapman LJ, McDowell LR (2003) Mineral resource availability and consumption by colobus in Kibale National Park, Uganda. Int J Primatol 24:541-573

Rode KD, Chapman CA, McDowell LR, Stickler C (2006) Nutritional correlates of population density across habitats and logging intensities in redtail monkeys (Cercopithecus ascanius). Biotropica 38:625-634

Rothman JM, Raubenheimer D, Chapman CA (2011) Nutritional geometry: gorillas prioritize non-protein energy while consuming surplus protein. Biol Lett 7:847-849

Schmid J, Ganzhorn JU (1996) Resting metabolic rates of Lepilemur ruficaudatus. Am J Primatol 38:169-174

Snaith TV, Chapman CA (2007) Primate group size and interpreting socioecological models: do folivores really play by different rules? Evol Anthropol 16:94-106

Stevenson PR (2001) The relationship between fruit production and primate abundance in Neotropical communities. Biol $\mathbf{J}$ Linn Soc 72:161-178

Sugiyama Y, Ohsawa H (1982) Population dynamics of Japanese monkeys with special reference to the effect of artificial feeding. Folia Primatol 39:238-263

Takasaki H (1981a) On the deciduous-evergreen zonal gap in the per capita range area of the Japanese macaque troop from north to south: a preliminary note. Physiol Ecol Jpn 18:1-5

Takasaki H (1981b) Troop size, habitat quality, and home range area in Japanese macaques. Behav Ecol Sociobiol 9:277-281
Tombak KJ, Reid AJ, Chapman CA, Rothman JM, Johnson CA, Reyna-Hurtado R (2012) Patch depletion behavior differs between sympatric folivorous primates. Primates 53:57-64

Tsuji Y, Kazahari N, Kitahara M, Takatsuki S (2008) A more detailed seasonal division of the energy balance and the protein balance of Japanese macaques (Macaca fuscata) on Kinkazan Island, northern Japan. Primates 49:157-160

van Schaik CP, Terborgh JW, Wright SJ (1993) The phenology of tropical forests: adaptive significance and consequences for primary consumers. Annu Rev Ecol System 24:353-377

van Schaik CP, Madden RH, Ganzhorn JU (2005) Seasonality and primate communities. In: Brockman DK, van Schaik CP (eds) Seasonality in primates: studies of living and extinct human and non-human primates. Cambridge University Press, Cambridge, pp 445-463

Vogel ER, Crowley BE, Knott CD, Blakely MD, Larsen MD, Dominy NJ (2012a) A noninvasive method for estimating nitrogen balance in free-ranging primates. Int $\mathbf{J}$ Primatol 33:567-587

Vogel ER, Knott CD, Crowley BE, Blakely MD, Larsen MD, Dominy NJ (2012b) Bornean orangutans on the brink of protein bankruptcy. Biol Lett 8:333-336

Wada K (1975) Ecology of wintering among Japanese monkeys in Shiga Heights and its adaptive significance (in Japanese). Physiol Ecol Jpn 16:9-14

Wallis IR, Edwards MJ, Windley H, Krockenberger AK, Felton A, Quenzer M, Ganzhorn JU, Foley WJ (2012) Food for folivores: nutritional explanations linking diets to population density. Oecologia 169:281-291

Watanabe K (1981) Variations in group composition and population density of the two sympatric Mentawaian leaf monkeys. Primates 22:145-160

Watanabe K, Mori A, Kawai M (1992) Characteristic features of the reproduction of Koshima Monkeys, Macaca fuscata fuscata: a summary of 34 years of observation. Primates 33:1-32

Waterman PG, Ross JAM, Bennett EL, Davies AG (1988) A comparison of the floristics and leaf chemistry of the tree flora in 2 Malaysian rain forests and the influence of leaf chemistry on populations of colobine monkeys in the Old World. Biol J Linn Soc 34:1-32

Weisenseel K, Chapman CA, Chapman LJ (1993) Nocturnal primates of Kibale Forest: effects of selective logging on prosimian densities. Primates 34:445-450

White TCR (1993) The inadequate environment: nitrogen and the abundance of animals. Springer, Berlin

White LJT (1994) Biomass of rain forest mammals in the Lope Reserve, Gabon. J Anim Ecol 63:499-512

Whitesides GH, Oates JF, Green SM, Kluberdanz RP (1988) Estimating primate densities from transects in a West African rain forest: a comparison of techniques. J Anim Ecol 57:345-367

Wich S, Buij R, van Schaik C (2004) Determinants of orangutan density in the dryland forests of the Leuser Ecosystem. Primates 45:177-182

Wieczkowski J (2004) Ecological correlates of abundance in the Tana mangabey (Cercocebus galeritus). Am J Primatol $63: 125-138$

Wolff JO (1996) Population fluctuations of mast-eating rodents are correlated with production of acorns. J Mammal 77:850-856

Worman CO, Chapman CA (2006) Densities of two frugivorous primates with respect to forest and fragment tree species composition and fruit availability. Int J Primatol 27:203-225

Yeager CP, Kirkpatrick RC (1998) Asian colobine social structure: ecological and evolutionary constraints. Primates 39:147-155

Yoshihiro S, Ohtake M, Matsubara H, Zamma K, Hanya G, Tanimura Y, Kubota H, Kubo R, Arakane T, Hirata T, Furukawa M, Sato A, Takahata Y (1999) Vertical distribution of wild Yakushima macaques (Macaca fuscata yakui) in the western area of Yakushima Island, Japan: preliminary report. Primates 40:409-415

Zhao QK (1994) Seasonal changes in body weight of Macaca thibetana at Mt-Emei, China. Am J Primatol 32:223-226 